\title{
A Study of Construction Management of Seismic Isolation Retrofit
}

\author{
About the Effective Utilization of Temporary Pile
}

\author{
Xuewen Bao* and Yasuhide Mochida \\ Dept. of Architecture and Urban Design College of \\ Science and Engineering, \\ Ritsumeikan Univ \\ Shiga, Japan \\ mochida@fc.ritsumei.ac.jp
}

\author{
Yukihito Nanbu \\ Shimizu Corporation \\ Osaka, Japan
}

\begin{abstract}
This study elaborated the process management and quality control of three typical major isolation retrofit projects in the construction stage of base seismic isolation by migrating the building load entrusted by the temporary pile to seismic isolation devices. About the process management, support ground depth was set as a parameter, the process period including the building area and building load were discussed. In the quality control, the impact on the process was generated by the difference of the vertical displacement of load migration and temporary supporting piles properties. The purpose of this study was to analyze the impact of the construction by applying temporary pile in the construction process of seismic isolation devices.
\end{abstract}

Keywords - seismic isolation retrofit; basic seismic isolation; temporary pile; ground; vertical displacement

\section{INTRODUCTION}

Japan, well known as earthquakes country, has many seismic isolation retrofit projects. The feature of this project is to reduce the seismatic reinforcement of the existing superstructure construction and maintain the use of the building while doing the construction. Therefore, most of the buildings are using the method of the basic seismic isolation. All of seismic isolation retrofit projects during the construction process of the isolation device shall migrate the superstructure load. In the two following methods, commonly used in superstructure load migration, one is to directly migrate the load of the superstructure into seismic isolation devices. The other one is to temporarily migrate superstructure load through the temporary pile, then migrate the load to the seismic isolation devices.

\section{The PRESENT CONDITION OF SEISMIC ISOLATION RETROFIT IN JAPAN}

Based on the different locations of isolation, there are two general types of isolation structure: Base isolation structure and the Mid-story isolation structure. Base isolation is the more popular basic structure of the seismic isolation. The general method of construction was to establish the isolation layer on the basis of the building, by setting the isolator and damper to make ground and buildings isolated. Fig. 1 shows three great earthquakes that occurred in Japan from 1994 to 2013 and their seismic isolation retrofit plan corresponding changes. When the Great Hanshin Earthquake of 1995 occurred, there was no building apply the technology of seismic isolation retrofit. This number gradually increased to 16 buildings in 5 years after the Chuetsu earthquake in 2004, it was only 6 buildings. Then reached the hill --- 16 buildings after just 3 years. Moreover, the 2011 Great East Japan earthquake suddenly turned from 5 buildings to 15 buildings in 1 year. As Fig. 1 shows, there is a certain degree of correlation between the planning building number of seismic isolation retrofit and the big earthquake. The growth rate of the planning building number of seismic isolation retrofit has increased significantly after the Great Hanshin Earthquake. About the types of seismic isolation planning after 2007, other parts of planning building more than the part of the Certification by Minister of Construction because of the issuing time of Certification by Minister of Construction.

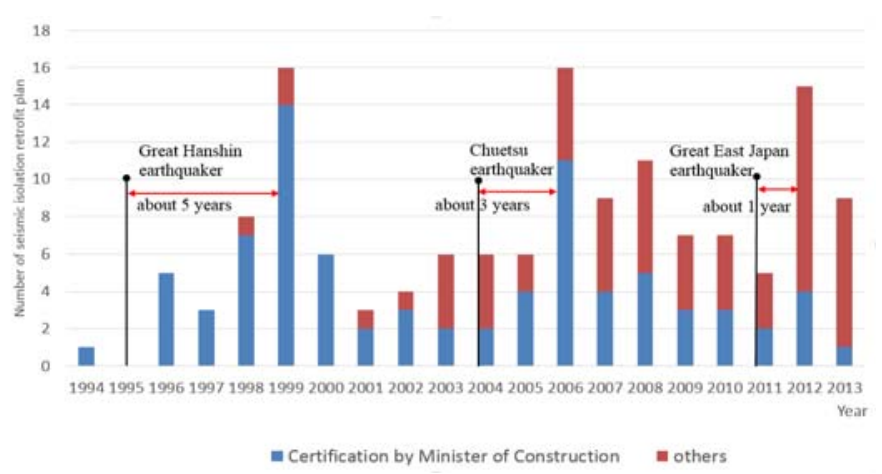

Fig. 1. Seismic isolation retrofit plans in Japan.

Fig. 2 shows the major proportion of the seismic isolation retrofit until 2010. The largest portion was government buildings which occupied for $38 \%$, buildings that have cultural values such as museums and temples accounted for $17 \%$ while the residential only has $6 \%$. The problems of safety and economy are in the construction of residential need to be addressed. Most of the planning of seismic isolation retrofit is applied on official buildings and public facilities until now 
though it is probable that the application of seismic isolation retrofit in private housing will be greatly increased in the future.

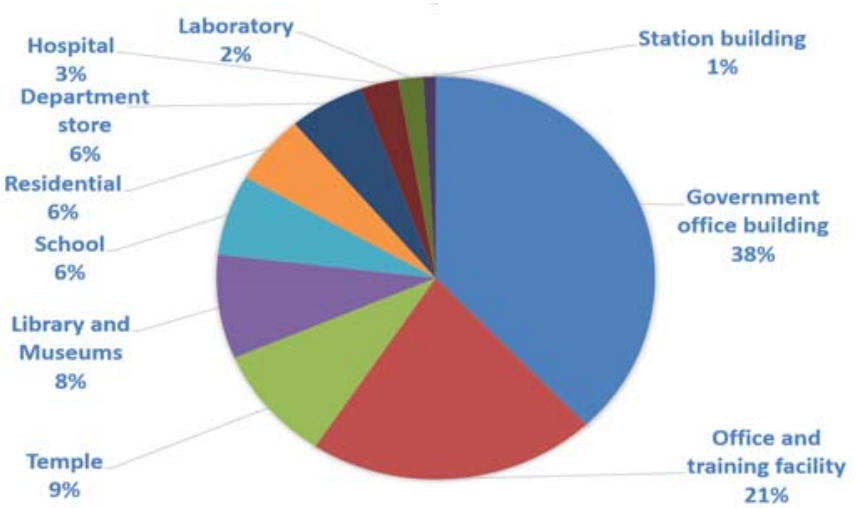

Fig. 2. The proportion of the seismic isolation retrofit.

\section{INTRODUCTION OF SEISMIC ISOLATION RETROFIT PROJECTS}

There are 3 typical major isolation retrofit projects. The summary of the projects is shown in Table I and the process schedule is displaced in the Fig. 3. These three buildings have great artistic and historic value, therefore base isolation retrofit technic was chosen.

\section{A. Introduction of Project $A$}

Building A, a steel reinforcement and brick structure, was completed in 1918. It was three floors over the ground and two floors underground. The saving and reproducing construction included reinforcement of roof steel truss and brick wall. The improvement of the seismic capacity of this building was achieved by the method of base isolation construction. In addition, before the seismic isolation retrofit construction started, it was found that the ground became like in liquefaction because of the high level of the groundwater and soft sandy. There was a significant difference in the rigidity of the ground in the east and west directions. The uneven settlement was proceeding, while the maximum tilt can reach to $200 \mathrm{~mm}$, it was necessary to apply settlement correction construction. A hydraulic jack (approximately 340) was installed in the top of the steel pile to make the settlement correction and controlled the load and displacement automatically.

Existing foundation was a concrete spread foundation that was combined with the pine pile. New footing beams including the old and the new were built in the both sides of the existing foundation. At the bottom of the existing building, a boxshaped underground foundation consisting of a new continuous underground wall and foundation batholith was built and incorporated the seismic isolation device between the foundation batholith and the existing building.

Moreover, it was more convenient to use two floors underground for the reason that the electrical room, water tank, and pump room require plenty of space for extension. Which had a minimal impact on the building plans and design.
TABLE I. SUMMARY OF THE PROJECTS

\begin{tabular}{|c|c|c|c|}
\hline & Project A & Project B & Project C \\
\hline $\begin{array}{c}\text { Construction } \\
\text { area(Existing) }\end{array}$ & $\begin{array}{c}2324.04 \mathrm{~m}^{2} \\
\left(2144.22 \mathrm{~m}^{2}\right) \\
\end{array}$ & $1982.289 \mathrm{~m}^{2}$ & $1692.6 \mathrm{~m}^{2}$ \\
\hline $\begin{array}{c}\text { Total floor } \\
\text { area(Existing) }\end{array}$ & $\begin{array}{c}9970.56 \mathrm{~m}^{2} \\
\left(8425.04 \mathrm{~m}^{2}\right)\end{array}$ & $5312.341 \mathrm{~m}^{2}$ & $\begin{array}{c}4200.30 \mathrm{~m}^{2} \\
\left(3995.61 \mathrm{~m}^{2}\right)\end{array}$ \\
\hline $\begin{array}{c}\text { Completion } \\
\text { time }\end{array}$ & 1918 & 1925 & 1959 \\
\hline $\begin{array}{l}\text { Number of } \\
\text { floors }\end{array}$ & $\begin{array}{l}3 \text { floors above } \\
\text { ground } \\
2 \text { floors under } \\
\text { ground }\end{array}$ & $\begin{array}{l}2 \text { floors above } \\
\text { ground } \\
1 \text { floor under } \\
\text { ground } \\
3 \text { floors tower }\end{array}$ & $\begin{array}{l}3 \text { floors above } \\
\text { ground } \\
1 \text { floor under } \\
\text { ground } \\
1 \text { floors tower }\end{array}$ \\
\hline Height & $\begin{array}{c}\mathrm{GL}+19.48 \mathrm{~m} \\
\text { The highest } \\
26.63 \mathrm{~m}\end{array}$ & $\begin{array}{c}\mathrm{GL}+19.574 \mathrm{~m} \\
\text { The highest } \\
31.574 \mathrm{~m}\end{array}$ & $\mathrm{GL}+9.86 \mathrm{~m}$ \\
\hline Foundation & $\begin{array}{l}\text { Continuous } \\
\text { footing and } \\
\text { Independent } \\
\text { footing }\end{array}$ & $\begin{array}{l}\text { Independent } \\
\text { footing }\end{array}$ & $\begin{array}{l}\text { Independent } \\
\text { footing }\end{array}$ \\
\hline $\begin{array}{l}\text { Construction } \\
\text { period }\end{array}$ & $\begin{array}{c}1999.3 \sim \\
2002.9 \\
43 \text { months }\end{array}$ & $\begin{array}{l}2001.9 \sim 2003.11 \\
21 \text { months }\end{array}$ & $\begin{array}{c}1996.5 \sim \\
1998.3 \\
23 \text { months }\end{array}$ \\
\hline Structure & $\begin{array}{c}\text { Steel } \\
\text { reinforcement } \\
\text { and brick } \\
\text { structure }\end{array}$ & $\begin{array}{c}\text { Reinforced } \\
\text { concrete } \\
\text { structure }\end{array}$ & $\begin{array}{c}\text { Reinforced } \\
\text { concrete } \\
\text { structure }\end{array}$ \\
\hline $\begin{array}{c}\text { Building } \\
\text { weight }\end{array}$ & $\begin{array}{l}\text { About } \\
30000 t\end{array}$ & $\begin{array}{l}\text { About } \\
14280 t\end{array}$ & $\begin{array}{l}\text { About } \\
11000 t\end{array}$ \\
\hline
\end{tabular}

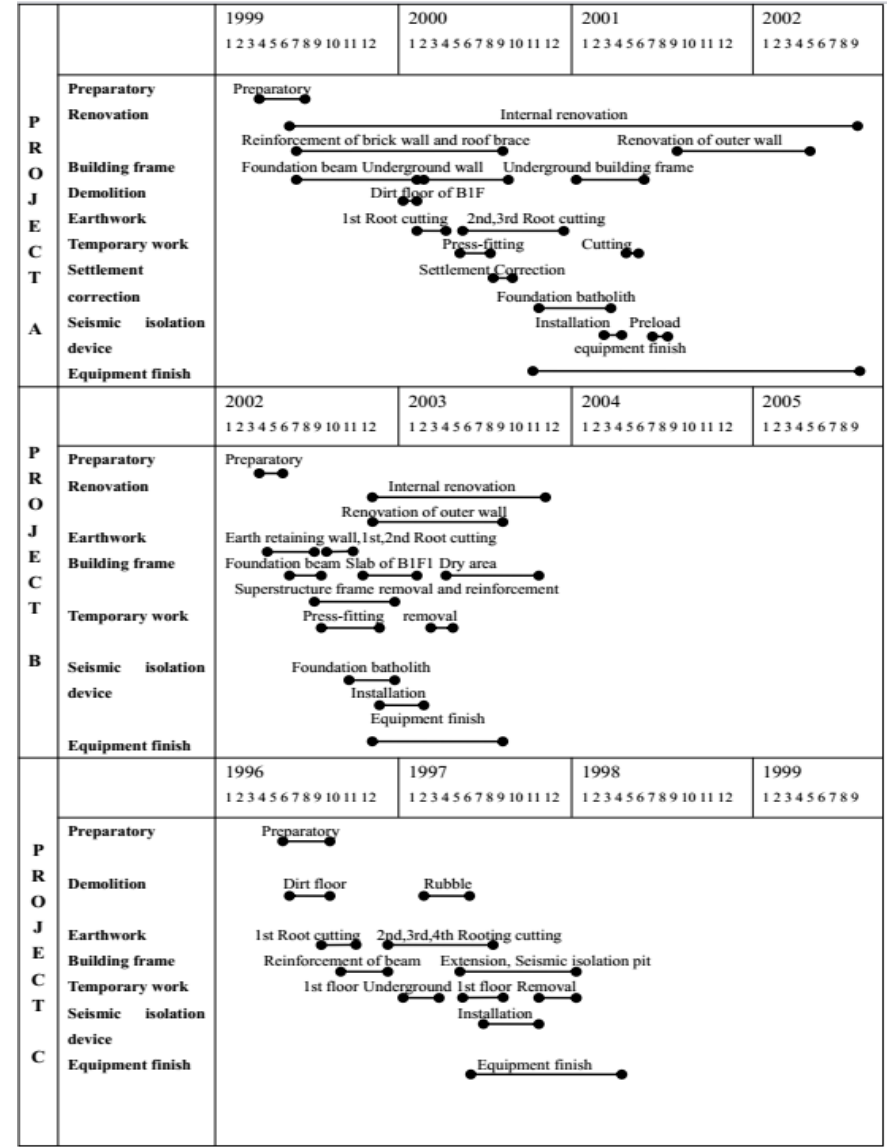

Fig. 3. The process schedule. 
About the construction process of project A. At first, it spent about 6 months on preparatory work, 15 months on the reinforce foundation beam and continuous underground wall construction, then a period of 11 months of the 1 st to 3 rd root cutting work. Thereafter, the building was temporarily received by the press-fit; the steel pipe pile and settlement correction construction was applied. After settlement correction, the construction, and installation of the foundation batholith of the seismic isolation device was consumed over 3 and 6 months respectively. In addition, it took 40 months for renovation and finishing touches of the entire building and 26 months to make the equipment completion work. The entire process was completed in 43 months.

\section{B. Introduction of Project $B$}

Building B, a reinforced concrete structure, was completed in 1925. It was two floors over the ground, one floor underground and another three floors for the clock tower. Entire renovation plan included the seismic isolation of main building and clock tower and the reinforcement of structural framework and internal renovation. Seismic isolation layer was built under the 1st floor of existing buildings, and a new foundation was built under the B1 floor. For the purpose of renovation of this building, the historical value of the building can be maintained through the improvement of a seismic performance. When only applied seismic reinforcement to new construction and expansion of the bearing wall and brace, it required a considerable amount of reinforcement because of the inferior horizontal strength of this building, which can be a great problem for its monument value. Therefore, the method of seismic isolation retrofit was adopted to reduce the seismic force that acts on the superstructure by installing seismic isolation device under the bottom layer, and meanwhile increased the strength of the superstructure by the new construction and increased thickness of shear walls and extension of pillars and beams.

About the construction process of project $\mathrm{B}$, at first, it took 2 months on preparatory work, 7 months in the 1 st to 2 nd root cutting work and another 12 months on the new foundation beam and new slab and dry area building construction work construction. Thereafter, the temporary work, from press-fit to removal steel pipe pile took 6 months. At the same time, foundation batholith construction and the installation of the seismic isolation device were took over 5 months. In addition, it took 12 months to renovate the entire building and 12 months to make the equipment completion work. The entire process was completed in 21 months.

\section{Introduction of Project $C$}

Building $\mathrm{C}$, a reinforced concrete structure, was completed in 1959. It was three floors over the ground and one floor underground. About the construction plan, a new base isolation layer was built by the installation of the seismic isolation device under the existing foundation. In particular, it was an important challenge because the base isolation was also used in the extension part of the first floor underground. Foundation type of the existing building was a spread foundation. The Kanto loam was used to bear ground. This construction included no basement, the extension underground and the part of the underground 1st floor. There was a level difference in the construction of seismic isolation layer. Therefore, it was a complex under-pinning construction.

About the construction process of project $\mathrm{C}$, at first, it spent 4 months on preparatory work and 11 months in the 1st to 4th root cutting work and removal of the first floor existing dirt floor concrete. Thereafter, the existing footing beams and press-fitted of the steel pipe pile was reinforced. Then, the foundation batholith was built, and the seismic isolation device installed, which was integrated with the existing foundation. In addition, equipment completion work took 11 months. The entire process was completed in 23 months.

For the time consuming on the seismic isolation retrofit of project A, B, C was 29, 21 and 22 months, respectively.

\section{SUMMARY AND DisCUSSION OF TEMPORARY STEEL PIPE PILE CONSTRUCTION}

Table II shows the summary of temporary steel pipe pile construction. About the diameter of steel pipe pile, the maximum diameter of project A was $\Phi 508.1 \times 7.9 \mathrm{~mm}$ and the minimum diameter of project A was $\Phi 318.5 \times 6.9 \mathrm{~mm}$. For the temporary steel pipe pile construction, 3 projects were used the same method: at first, excavated under the existing foundation for each zone. Then, hydraulic jack was installed under the existing footing beams, press-fitting the steel pipe pile by the reaction force of existing building. Press-fitting used the jack stroke and adjustment piece between the pile head. Adjustment piece was integrated with pile body by field welding every time when it was pressed. The shape and weight of the steel pipe were determined by the workability of underpinning construction and the carry-possible weight by the human power of a good handling length about $1 \mathrm{~m}$. The magnitude of steel pipe diameter was determined by the expected pile bearing capacity at the time of temporary, it was evaluated by the equation:

$$
R a=\alpha * \mathrm{~N} * \mathrm{Ap}
$$

In this equation, $\alpha$ is the experience factor, $\mathrm{N}$ is the pile tip average $\mathrm{N}$-value of the ground and $\mathrm{Ap}$ is the diameter that surrounded by the pile outside. There were 3 types of steel pipe were used in project B, caused by the different temporarily received load of the pillar and the various pile tip N-value of the ground.

For the number of the pile, project A was 346 piles, project $\mathrm{B}$ was 163 piles and project $\mathrm{C}$ was 158 piles. After calculated the burden load per one by building weight / pile number, project $\mathrm{A}$ was $87 \mathrm{t}$, project $\mathrm{B}$ was $87 \mathrm{t}$ and project $\mathrm{C}$ was $70 \mathrm{t}$. The average of design pile bearing capacity was $900 \mathrm{KN}$ in all projects. Thus, in all projects, the burden load per pile was lower than the design pile bearing capacity. For the calculation of the pile number, it was able to grasp the general pile number by the equation:

$\mathrm{W} / \mathrm{P} / 900 *(1.05 \sim 1.3)$ 
TABle II. Summary of Temporayr SteEl Pipe Pile CONSTRUCTION

\begin{tabular}{|c|c|c|c|}
\hline & Project A & Project B & Project C \\
\hline $\begin{array}{l}\text { Steel pipe pile } \\
\left(\mathrm{mm}^{2}\right)\end{array}$ & $\varphi 508 . \quad 1 \times 7.9$ & 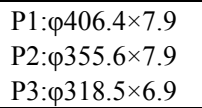 & $\varphi 355.6 \times 7.9$ \\
\hline $\begin{array}{l}\text { Building } \\
\text { weight: } \mathrm{W}(\mathrm{t})\end{array}$ & About 30000 & About 14280 & About 11000 \\
\hline $\begin{array}{l}\text { Number of the } \\
\text { pile: } \\
\text { P }\end{array}$ & 346 & $\begin{array}{l}\text { P1:89 } \\
\text { P2:38 } \\
\text { P3:36 } \\
\text { Sum:163 }\end{array}$ & $\begin{array}{l}\text { 1floor: } 92 \\
\text { B1 floor: } 66 \\
\text { Sum: } 158\end{array}$ \\
\hline $\begin{array}{l}\text { Load per pile: } \\
\text { W/P (t) }\end{array}$ & 87 & 87 & 70 \\
\hline $\begin{array}{l}\text { Design pile } \\
\text { bearing } \\
\text { capacity } \\
\text { (KN) }\end{array}$ & $\begin{array}{l}900 \\
\text { (Long term) }\end{array}$ & $\begin{array}{l}\text { P1:1000 } \\
\text { P2:800 } \\
\text { P3:650 } \\
\text { (Medium term) }\end{array}$ & $\begin{array}{l}900 \\
\text { (Medium term) }\end{array}$ \\
\hline $\begin{array}{l}\text { Per pile length: } \\
\text { L (m) }\end{array}$ & 7 & 7 & 10 \\
\hline $\begin{array}{l}\text { Whole pile } \\
\text { length }(\mathrm{m}) \\
: \Sigma \mathrm{L}=\mathrm{P} \times \mathrm{L}\end{array}$ & $7 \times 346=2422$ & $7 \times 163=1141$ & $10 \times 158=1580$ \\
\hline $\begin{array}{l}\text { Period of press- } \\
\text { fitting(T) }\end{array}$ & $\begin{array}{l}2000.5 .19 \sim \\
8,23 \\
\text { (3 months) }\end{array}$ & $\begin{array}{l}2002.9 \sim 2003.1 \\
\text { (5months) }\end{array}$ & $\begin{array}{l}\text { 1996. 12.19 } \\
\text { 1997. 3.6 } \\
\text { (1 floor) } \\
\text { (2.5months) } \\
\text { 1997. 6.12 } \\
\text { 1997. } \\
9.18 \text { (B1) } \\
\text { (3months) }\end{array}$ \\
\hline $\begin{array}{l}\text { Number of } \\
\text { press-fitting } \\
\text { pile per } \\
\text { day :P/T } \\
\end{array}$ & $\begin{array}{l}346 / 3 \text { months }= \\
3.85 \text { piles/day }\end{array}$ & $\begin{array}{l}163 / 5 \text { months }= \\
1.08 \text { piles/day }\end{array}$ & $\begin{array}{l}158 / 5.5 \text { months } \\
=0.95 \\
\text { piles/day }\end{array}$ \\
\hline $\begin{array}{l}\text { Length of the } \\
\text { pile per day: } \\
\Sigma \text { L/T }\end{array}$ & $\begin{array}{l}2422 / 3 \text { months } \\
=27 \mathrm{~m} / \text { day }\end{array}$ & $\begin{array}{l}1141 / 5 \mathrm{months} \\
=7.6 \mathrm{~m} / \text { day }\end{array}$ & $\begin{array}{l}1580 / 5.5 \mathrm{months} \\
=9.6 \mathrm{~m} / \mathrm{day}\end{array}$ \\
\hline $\begin{array}{l}\text { Press-fitting } \\
\text { depth } \\
\text { :from GL(m) }\end{array}$ & 15 & $\begin{array}{l}\text { P1:7.69 } \\
\text { P2:8.13 } \\
\text { P3:7.54 }\end{array}$ & $\begin{array}{l}\text { Min:12.17 } \\
\operatorname{Max}: 20.70\end{array}$ \\
\hline $\begin{array}{l}\text { Press-fitting } \\
\text { load } \\
(\mathrm{KN})\end{array}$ & 2700 & $\begin{array}{l}\text { P1:2000 } \\
\text { P2: } 1600 \\
\text { P3:1300 }\end{array}$ & 1800 \\
\hline $\begin{array}{l}\text { Preload load } \\
(\mathrm{KN})\end{array}$ & 800 & $\begin{array}{l}\text { P1:1000 } \\
\text { P2:800 } \\
\text { P3:650 }\end{array}$ & 900 \\
\hline
\end{tabular}

For the length of the pile, project $\mathrm{A}$ and project $\mathrm{B}$ were about $7 \mathrm{~m}$, project $\mathrm{C}$ was about $10 \mathrm{~m}$. The whole extension length of the pile was calculated by the pile length and the pile number, project A was $2422 \mathrm{~m}$, project B was $1141 \mathrm{~m}$, and project $\mathrm{C}$ was $1580 \mathrm{~m}$. For the period of press-fitting work, project $\mathrm{A}, \mathrm{B}$, and $\mathrm{C}$ was 3,5 and 5.5 months, respectively. The number of the piles per day was calculated by the pile number/the period of press-fitting work, project A was 3.85 piles/day, project $\mathrm{B}$ was 1.08 piles/day and project $\mathrm{C}$ was 0.95 piles/day. It was able to be calculated the whole extension pile length per day by the whole pile length/the period of pressfitting work, project A was $27 \mathrm{~m} /$ day, project B was $7.6 \mathrm{~m} /$ day and project $C$ was $9.6 \mathrm{~m} /$ day. Therefore, project $\mathrm{A}$ had a high productivity, projects $\mathrm{B}$ and project $\mathrm{C}$ was about 1 pile/day and about $8 \mathrm{~m} /$ day.
Fig. 4 shows the result of standard penetration test of site ground. The steel pipe pile was pressed into a depth position where the pile bearing capacity could be expressed. There was a risk of liquefaction in project A because of the high level of underground water and the soft sandy ground.

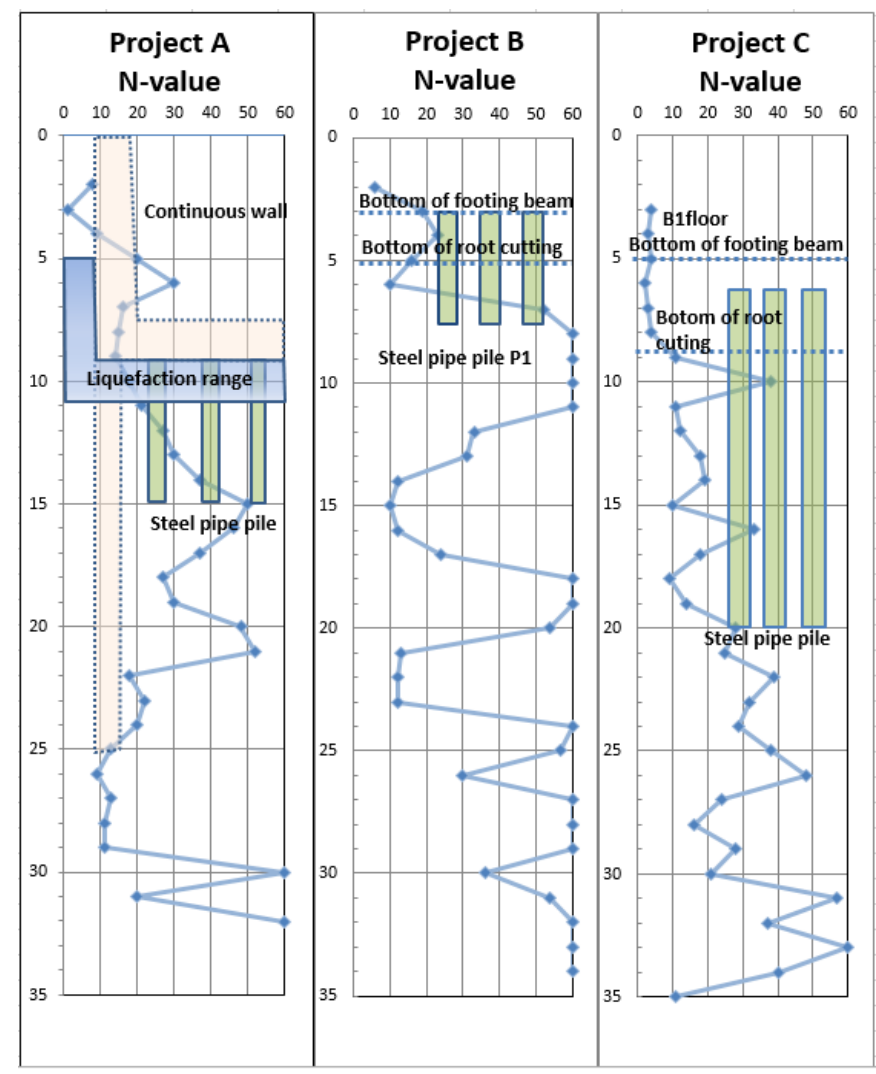

Fig. 4. The result of standard penetration test of site ground.

Even after the top of the steel pipe pile has been removed, the steel pipe pile under the foundation batholith was remained to support the foundation batholith. Thereby, during the earthquake, if the ground liquefies, the temporary received steel pipe pile that has remained in the foundation batholith could support building load. The press-fitting depth of steel pipe pile of project $B$ was the shallowest, reached the bearing ground in about $8 \mathrm{~m}$. Press-fitting depth of project $\mathrm{C}$ was the deepest, which had a low risk of liquefaction because the underground water level was GL-18m. Thus, project B was considered to be a hard ground as compared with project $\mathrm{B}$ and project C.

\section{Results and Discussion of DisPlacement of SteEl PIPE PILE MigRATED LOAD}

Table III shows the summary of the vertical displacement measuring management and Fig. 5, 6, 7 shows the plan view of the vertical displacement measuring point. For the vertical displacement, in order to manage the level of the building, project $\mathrm{B}$ and $\mathrm{C}$ used automatic measurement by water leveling type sink measurement, while project A used visual management by communication water pipe level. 
TABLE III. SUMMARY OF MEASURING MANAGEMENT

\begin{tabular}{|c|c|c|c|}
\hline & Project A & Project B & Project C \\
\hline $\begin{array}{c}\text { Number of } \\
\text { measurement } \\
\text { points }\end{array}$ & 14 & 30 & 10 \\
\hline $\begin{array}{c}\text { Measurement } \\
\text { period }\end{array}$ & $\begin{array}{c}2000.9 .18 \sim \\
2001.5 .17\end{array}$ & $\begin{array}{c}2002.8 .20 \sim \\
2003.4 .17\end{array}$ & \begin{tabular}{c}
$1996.12 .11 \sim 1997.12 .19$ \\
\hline $\begin{array}{c}\text { Reference } \\
\text { value of } \\
\text { subsidence } \\
\text { management }\end{array}$
\end{tabular} \\
\hline
\end{tabular}

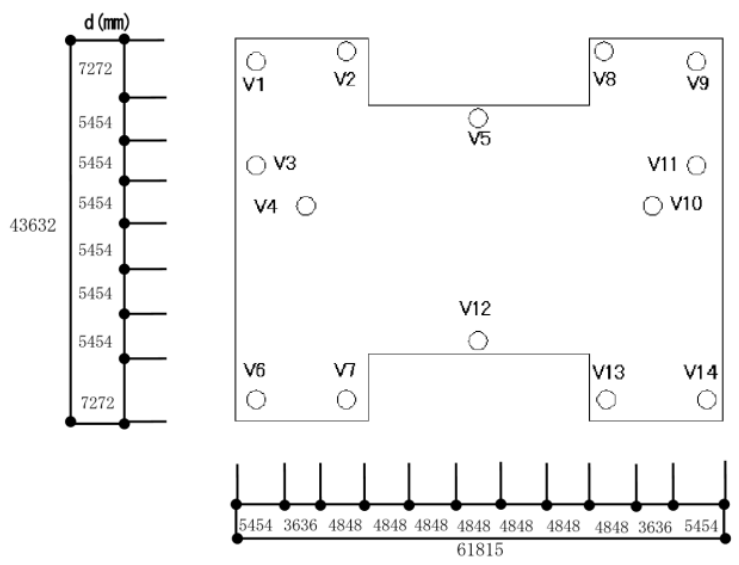

Fig. 5. Plan view of the vertical displacement measuring point in project A.
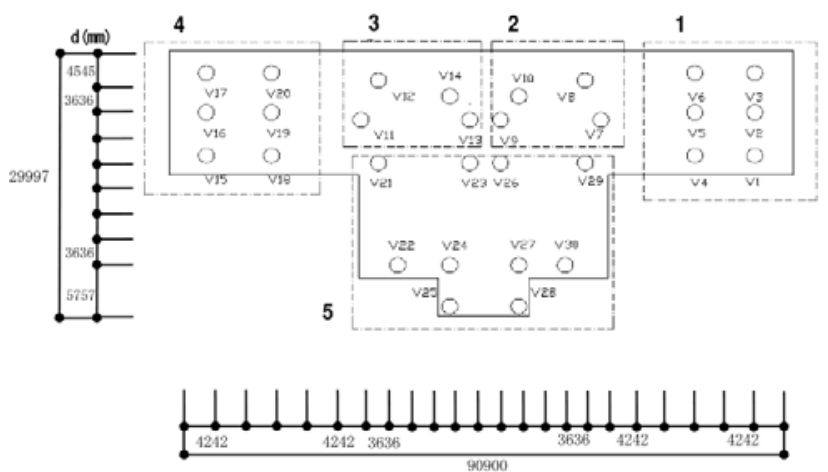

Fig. 6. Plan view of the vertical displacement measuring point in project B.

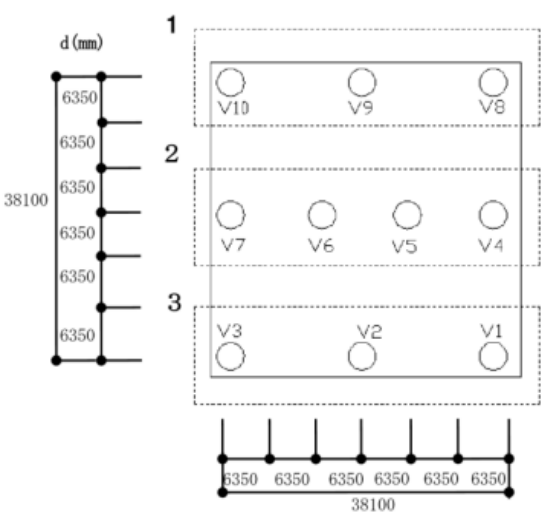

Fig. 7. Plan view of the vertical displacement measuring point in project $\mathrm{C}$.
Fig. 8 shows the vertical displacement variation of measurement pile V5, V6, V7, V12 in project A. The sign "V" takes the first letter of "VERTICAL DISPLACEMENT" and the numbers indicate the position of the measurement pile. "-" is subsidence, "+" is raise. Reference value of the measurement was set after settlement correction construction. Tendency of the vertical variation of the measurement pile, it was able to determine the vertical variation that was almost changed in the process. Building level had minor changes of " \pm " several millimeters during the period of temporary receiving after settlement correction construction. Maximum variation was about $6 \mathrm{~mm}$ of V7. There was slightly raised due to rebound during excavation. Thereafter, there was minor subsidence due to the construction of foundation batholith and the increase of superstructure. In addition, there was a small variation due to preloaded seismic isolation device. It could be considered the under-pinning construction was processed safely.

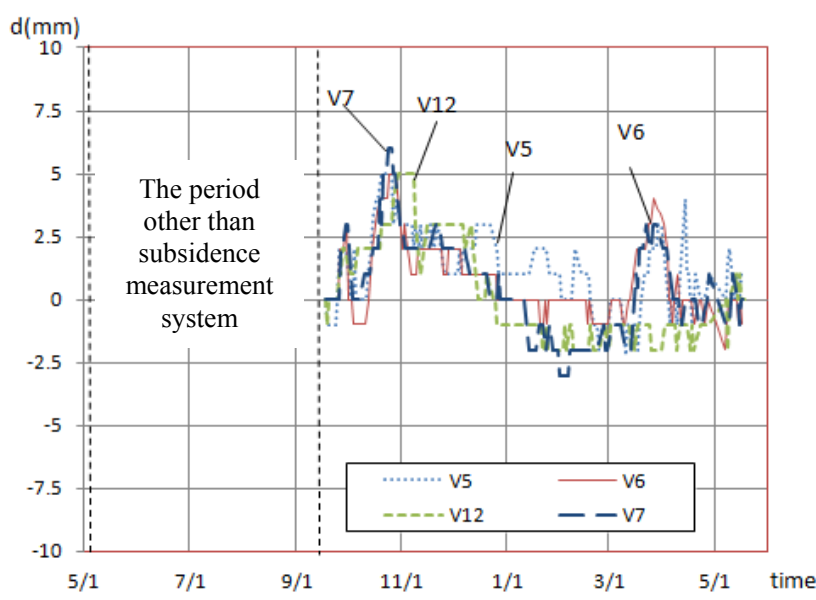

Fig. 8. Vertical displacement variation of measurement pile in project A.

The vertical displacement of project B had almost the same changes occurred at each measurement location. As a representative, Fig. 9 shows the vertical displacement variation of measurement pile V21, V25, V27, V29 in NO.5 construction zone. There was subsidence tendency of the vertical displacement of the building due to the temporary steel pipe pile construction. Furthermore, there was clearly subsidence resulting, especially during replacing the temporary steel pipe pile. That was because the Maximum axial force of 7/18 piles in construction exceeded the design bearing capacity, particularly all of the type P3 steel pipe piles were exceeding the design bearing capacity in NO.5 construction zone. Thereby, it was believed that with the additional influence of the ground property, subsidence has occurred. There was significant discontinuity subsidence occurred during temporary receiving after the preload of steel pipe pile, then, subsidence tendency was close to the linearity, and processed in a stable state. Comparing V25 in the south side to the other steel pipe pile, it appeared great subsidence, and among them the maximum subsidence was about $-22 \mathrm{~mm}$. In addition, when replaced the temporary pile to the seismic isolation device, there was subsidence tendency, for about $3 \mathrm{~mm}$. It was possible caused by the influence of the compactness of seismic isolation device. 


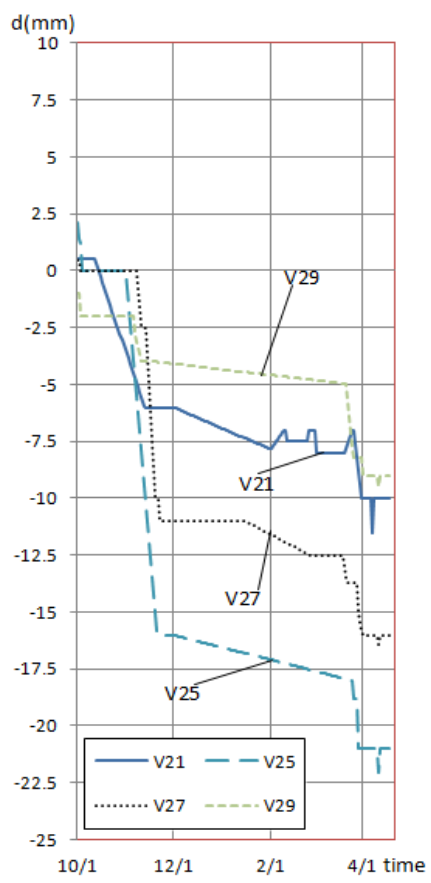

Fig. 9. Vertical displacement variation of measurement pile in project B.

Fig. 10 shows the vertical displacement variation of measurement pile of NO.2 construction zone in project C. Especially when replacing the temporary pile, there was a huge difference between project $B$ and project $C$. The variation of measurement pile of project $B$ was not in subsidence but raise. Therein, V5, V6, V7 of No.2 construction zone on the 1st floor underground did not occur off the vertical displacement. Then, when replaced the temporary pile to the seismic isolation, subsidence discontinuity occurred. V5, V6, V7 also showed a very slight variation.

In addition, except the 1st floor underground of the V5, V6, V7, from measurement started until the period of temporary received, the vertical subsidence tendency was close to the linearity with process progressed. The maximum amount of displacement was V4. Comparing the displacement of V5, V6, V7 to other steel pipe pile, it was minor $0.38 \mathrm{~mm}$ at most.

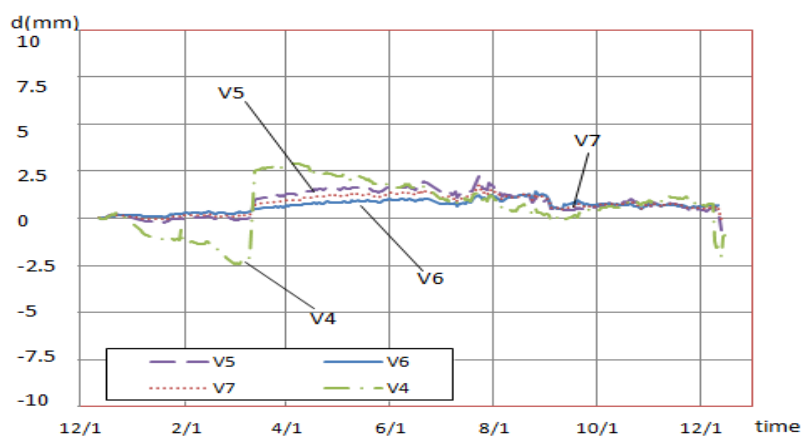

Fig. 10. Vertical displacement variation of measurement pile in project $\mathrm{C}$.

\section{CONCLUSION}

Seismic isolation retrofit is a very practical building technology in japan. This study mainly compared the data of three representative projects in process management and quality control of seismic isolation retrofit. The vertical displacement of the building during the period of temporary received construction by steel pipe pile and the significant results of press-fitting steel pipe piles were also discussed.

Because the seismic isolation retrofit is mainly the construction of the underground part, the situation of the underground floor and the ground of the existing building is the significant influence on process management. Therefore, it is very important to take the field investigation before the construction.

Moreover, in order to ensure the safety of construction, when managed the vertical displacement of the building, it is necessary to pay attention to the great variation of the building appearing when process raises or subsidence, especially during the migration work of temporary steel pipe piles. In those projects, temporary steel pipe piles were not only temporarily used in migrating the load of the building, but also used in settlement correction construction and effectively falsework to compress force of underground space extension work. Even after removing the top of the steel pipe pile, the foundation batholith has remained under it. If liquefaction or other unexpected situation emerged, the temporarily received steel pipe pile that remained in the foundation batholith could support building load. Thereby, temporary steel pipe pile is an effective device of seismic isolation retrofit construction.

\section{REFERENCES}

[1] T. Akira, I. Akihiro, N. Ryugo, A. Fumiaki, N. Kouichi, M. Yasuhide and A. Minoru, "The seismic isolation retrofit of National Museum of Western Art," Architectural Technology, vol.10, pp.217-230, October 1997.

[2] Shimizu; Nishimatsu; Daitetsu Specific Construction Joint Venture Measurement Engineering Inc, "Measurement result summary of Osaka Central Public Hall restoration construction," October 2000.

[3] Shimizu; Obayashi; Kajima Specific Construction Joint Venture Measurement Engineering Inc, "Measurement result summary of Kyoto University Clock Tower Centennial Hall restoration construction," April 2002. 